\title{
Radioactivity concentrations and dose assessment for bitumen and soil samples around a bituminous deposit in Ondo State, Nigeria
}

\author{
J.A. ADEMOLA ${ }^{1}$, S. ADEMONEHIN ${ }^{1}$
}

(Manuscript received 23 February 2010, accepted 22 April 2010)

ABSTRACT Bitumen samples and soil samples around a bituminous deposit in Ondo State, Nigeria, were analysed for ${ }^{40} \mathrm{~K},{ }^{226} \mathrm{Ra}$ and ${ }^{232} \mathrm{Th}$ employing gamma-ray spectrometry. The activity concentrations of ${ }^{40} \mathrm{~K},{ }^{226} \mathrm{Ra}$ and ${ }^{232} \mathrm{Th}$ in soil varied from $(45.2 \pm 5.3)$ to $(484.2 \pm 25.9)$, BDL (below detectable limit) to $(27.7 \pm 2.1)$ and $(22.8 \pm$ $2.7)$ to $(62.4 \pm 6.8) \mathrm{Bq} . \mathrm{kg}^{-1}$, respectively. The corresponding mean values were $(240.2 \pm 133.5),(13.3 \pm 8.0)$ and $(40.0 \pm 10.2) B q . \mathrm{kg}^{-1}$, respectively. The mean activity concentrations of the radionuclides in the bitumen were $(58.4 \pm 36.4),(16.1 \pm 13.3)$ and $(32.5 \pm 13.1) \mathrm{Bq} \cdot \mathrm{kg}^{-1}$, respectively, for ${ }^{40} \mathrm{~K},{ }^{226} \mathrm{Ra}$ and ${ }^{232} \mathrm{Th}$. The mean absorbed dose and effective dose for the soil samples were $(41.5 \pm 8.9) \mathrm{nGy}^{-\mathrm{h}^{-1}}$ and $(50.7 \pm$ 10.9) $\mu \mathrm{Sv} . \mathrm{y}^{-1}$, respectively, while those of the bitumen samples were $(29.5 \pm$ 15.6) $\mathrm{nGy.h}^{-1}$ and $(36.1 \pm 19.1) \mu S v . \mathrm{y}^{-1}$, respectively. For radiological hazard assessment, the radium equivalent activity and the external hazard index were determined. The values of the radium equivalent activity and external hazard index obtained for the soil and bitumen samples were lower than the recommended limit.

Keywords: Activity concentration / natural radionuclides / dose assessment / bitumen / soil / Nigeria

RÉSUMÉ Radioactivité et évaluation de la dose dans des échantillons de bitume et de sol autour d'un dépôt bitumineux dans l'état d'Ondo, Nigéria.

${ }^{40} \mathrm{~K},{ }^{226} \mathrm{Ra}$ et ${ }^{232} \mathrm{Th}$ ont été analysés par spectrométrie gamma dans des échantillons de bitume et de sol autour d'un dépôt bitumineux dans l'état d'Ondo, Nigeria. Les concentrations en ${ }^{40} \mathrm{~K},{ }^{226} \mathrm{Ra}$ et ${ }^{232}$ Th dans le sol varient respectivement de $(45,2 \pm$ $5,3)$ à $(484,2 \pm 25,9)$, SLD (sous la limite de détection) à $(27,7 \pm 2,1)$ et de $(22,8 \pm 2,7)$ à $(62,4 \pm 6,8) \mathrm{Bq} \cdot \mathrm{kg}^{-1}$. Les valeurs moyennes correspondantes sont respectivement $(240,2 \pm 133,5),(13,3 \pm 8,0)$ et $(40,0 \pm 10,2) \mathrm{Bq} \mathrm{kg}^{-1}$. Les concentrations moyennes dans les bitumes sont de $(58,4 \pm 36,4),(16,1 \pm 13,3)$ et $(32,5 \pm 13,1) \mathrm{Bq} \mathrm{kg}^{-1}$, respectivement pour le ${ }^{40} \mathrm{~K},{ }^{226} \mathrm{Ra}$ et le ${ }^{232} \mathrm{Th}$. La dose absorbée moyenne et la dose effective moyenne dans les échantillons de sol sont respectivement de $(41,5 \pm 8,9) \mathrm{nGy}^{-\mathrm{h}^{-1}}$ et $(50,7 \pm$ 10,9) $\mu \mathrm{Sv} . \mathrm{y}^{-1}$, alors que celles dans les échantillons de bitume sont respectivement de $(29,5 \pm 15,6) \mathrm{nGy}^{-1}$ et $(36,1 \pm 19,1) \mu S v \cdot \mathrm{y}^{-1}$. Pour évaluer le détriment radiologique, l'activité équivalente en radium et l'indice de détriment externe ont été déterminés. Les valeurs obtenues pour les échantillons de sol et de bitume sont inférieures aux limites recommandées.

\footnotetext{
1 Department of Physics, University of Ibadan, Ibadan, Nigeria.
} 


\section{Introduction}

Our world is radioactive and has been since it was created. Over 60 radionuclides (radioactive elements) can be found in nature, and can be placed into three general categories: primordial (formed before the creation of the earth), cosmogenic (formed as a result of cosmic ray interactions) and human-produced (enhanced or formed due to human actions) (Kathren, 1991). The exposure of human beings to ionising radiation from natural sources is a continuing and inescapable feature of life on earth. For most individuals, this exposure exceeds that from all man-made sources combined. Both external and internal exposures to humans arise from these sources (UNSCEAR, 2000).

Radioactive elements occur in trace amounts in all rocks and minerals and many are readily detectable by the gamma radiation emitted during their decay. The fraction of the background dose rate to man from environmental gamma radiation is very variable and depends on factors such as the radioactivity of the local rock and soil, the nature of building materials and the construction of buildings in which people live and work. Natural radioactivity is associated with natural sources such as uranium deposits, and oil and natural gas fields (Boyle, 1982). External radiation exposures from naturally occurring radionuclides have been reported to contribute about half of the average annual dose to humans from all radiation sources (CBEIR NRC, 1988).

Bitumen, popularly known as tarsand, is formed from biodegradation of crude oil by certain bacteria such as Pseudomonas stutzeri, Pseudomonas mullei and Alcaligenes sp. Tarsand is composed of sand, heavy oil and clays that are rich in minerals and water. The heavy oil in tarsand is called bitumen. Nigeria is richly endowed with many natural resources; the most important are crude oil, gas and bitumen. Of all the three natural resources, only the crude oil has been well developed and it contributes about 90\% to the country's foreign earnings (Adegoke et al., 1991). The Nigerian bitumen belt lies on the onshore areas of the eastern Dahomey (Benin) Basin. The probable reserve of bitumen and heavy oil in the entire Nigerian belt is about $120 \mathrm{~km} \times 4.3 \mathrm{~km}$ (Adegoke and Ibe, 1982). The Nigerian bitumen possesses a relatively large quantity of naphthenes, aromatics and asphaltenes that are similar to those in conventional oil. This makes the Nigerian bitumen a very useful alternative source of petroleum hydrocarbon and a potential feedstock for petrochemical industries (Adegoke et al., 1991). Bitumen, when mixed with other materials, could be used as a sealant, adhesive, building mortar, incense, and decorative application on pots and buildings. The material is also useful in waterproofing canoes and other water transport. In Nigeria, bitumen is mainly used for construction of roads. 
The study location, Agbabu in Ondo State, Nigeria, falls within latitudes $6^{\circ} 35^{\prime}$ and $6^{\circ} 39^{\prime} \mathrm{N}$ and longitudes $4^{\circ} 48^{\prime}$ and $4^{\circ} 54^{\prime} \mathrm{E}$. The place was chosen because of the abundance of deposits of bitumen in the region. The area falls within the Nigerian sector of the Dahomey basin. It was shown to be a coastal, sedimentary, marginal pull-apart basin. The bitumen is found impregnating sedimentary deposits previously referred to as the Abeokuta Formation (Omatsola and Adegoke, 1981). Three Formations belonging to the Abeokuta group are recognised: the Ise, Afowo and Araromi Formations. The main habitat for the bituminous sands is the Afowo Formation, which is made up of a thick sequence of sands, interbedded with organic shale and siltstones. The tar-bearing sands occur as two distinct stratigraphic bands separated by uniformly thick shale (Enu, 1994). The thickness of the oil shale ranges between 6 and $15 \mathrm{~m}$, and the average thickness of the tar sand horizons is about $12 \mathrm{~m}$.

Renewed interest in the exploration and exploitation of the vast bituminous sand deposit of Nigeria and recent reported cases of possible high levels of radioactive materials in some bituminous nodules in the Czech Republic (Kribek et al., 1999) emphasise the need for new studies on the presence and level of radioactivity in the bituminous sand of Ondo State, Nigeria. This study aimed at using radiometric analysis for the determination of activity concentrations of primordial radionuclides, potassium-40, radium-226 and thorium-232, in bitumen and soil samples collected from a bituminous deposit in Ondo State, Nigeria, and evaluates the radiological implications.

\section{Materials and methods}

Three sets of samples were collected from the study location. They are:

a. core bitumen - represents bitumen sample seeping out directly from installation pipes;

b. surface bitumen - represents bitumen sample collected from surfaces of the soil and;

c. soil samples - represent relatively undisturbed soil in the vicinity of the sampling station.

The soil samples were collected at a depth of $10 \mathrm{~cm}$ using a hand trowel. Thirtyeight soil samples and two bitumen samples were collected. The soil samples were dried under laboratory conditions until a constant weight was obtained. The soil samples were ground and a mass of $200 \mathrm{~g}$ each was weighed and put in plastic containers. The bitumen samples were also put in plastic containers without any processing. The samples were sealed and left for more than 28 days, a period considered sufficient for the attainment of secular equilibrium of $\mathrm{Ra}$ and its shortlived progeny. 
The detector used for the radioactivity measurements is a lead-shielded $7.6 \mathrm{~cm} \times 7.6 \mathrm{~cm} \mathrm{NaI}(\mathrm{Tl})$ detector crystal (802 series Canberra Inc.) coupled to a Canberra series 10 plus multichannel analyser (MCA) (model number: 1102) through a preamplifier base. The detector has a resolution of about $8 \%$ at energy of $0.662 \mathrm{MeV}\left({ }^{137} \mathrm{Cs}\right)$, which is considered adequate to distinguish the gamma-ray energies of interest in the present study. Energy calibration was done using gamma sources from Nucleus Inc., Oak Ridge, TN, USA. The detection efficiency calibration of the system was carried out using the reference standard source prepared from Rocketdyne Laboratories, Canoga Park, California, USA, which is traceable to a mixed standard source by Analytic Inc., Atlanta, Georgia.

The radium content of the samples was determined from the intensity of the $1.765 \mathrm{MeV}$ photopeak of ${ }^{214} \mathrm{Bi}$. The thorium content was from the $2.610 \mathrm{MeV}$ photopeak from ${ }^{208} \mathrm{Tl}$ and the potassium content was from the $1.465 \mathrm{MeV}$ photopeak following the decay of ${ }^{40} \mathrm{~K}$. Each sample was counted for $10 \mathrm{~h}$ and the net count, $A$, under each photopeak was related to the detection efficiency, $E_{p}$, to obtain the activity concentrations of the radionuclides (Farai and Ademola, 2005)

$$
E_{p}=\frac{A}{t c y m} .
$$

where $t$ is the counting time, $c$ is the activity concentration, $y$ is the gamma yield and $m$ is the mass of the sample. The lower limits of detection (LLD) of ${ }^{40} \mathrm{~K},{ }^{226} \mathrm{Ra}$ and ${ }^{232} \mathrm{Th}$ were determined from the background radiation. This is an estimate for the lowest amount of activity of a specific gamma-emitting radionuclide that can be detected at the time of measurement (IAEA, 1989). The LLD obtained were 16.3, 4.0 and 4.7 Bq. $\mathrm{kg}^{-1}$, respectively, for ${ }^{40} \mathrm{~K},{ }^{226} \mathrm{Ra}$ and ${ }^{232} \mathrm{Th}$. Activity concentrations of radionuclides below these values were taken in this work as being below the detectable limit (BDL) of the detector.

\section{Results and discussion}

\subsection{Activity concentrations}

The activity concentrations of ${ }^{40} \mathrm{~K},{ }^{226} \mathrm{Ra}$ and ${ }^{232} \mathrm{Th}$ (Tabs. I and II) varied from $(45.2 \pm 5.3)$ to $(484.2 \pm 25.9)$, BDL to $(27.7 \pm 2.1)$ and $(22.8 \pm 2.7)$ to $(62.4 \pm$ $6.8) \mathrm{Bq} \cdot \mathrm{kg}^{-1}$ with mean values of $(240.2 \pm 133.5),(13.3 \pm 8.0)$ and $(40.0 \pm$ 10.2) Bq. $\mathrm{kg}^{-1}$, respectively, for the soil samples. The mean activity concentrations of the natural radionuclides in the bitumen samples were $(58.4 \pm 36.4),(16.1 \pm$ 13.3) and $(32.5 \pm 13.1) \mathrm{Bq} \cdot \mathrm{kg}^{-1}$, respectively, for ${ }^{40} \mathrm{~K},{ }^{226} \mathrm{Ra}$ and ${ }^{232} \mathrm{Th}$. The ${ }^{40} \mathrm{~K}$ and ${ }^{232} \mathrm{Th}$ contents of the soil samples were higher than those of the bitumen samples. However, the mean activity concentrations of ${ }^{40} \mathrm{~K},{ }^{226} \mathrm{Ra}$ and ${ }^{232} \mathrm{Th}$ obtained for both the soil and bitumen samples are lower than the world averages of 420, 33 and $45 \mathrm{~Bq} \cdot \mathrm{kg}^{-1}$, respectively (UNSCEAR, 2000). 


\section{TABLE I}

Activity concentrations of soil samples.

Concentrations dans les échantillons de sol.

\begin{tabular}{|c|c|c|c|}
\hline$S / N$ & ${ }^{40} \mathrm{~K}\left(\mathrm{~Bq} \cdot \mathrm{kg}^{-1}\right)$ & ${ }^{226} \mathrm{Ra}\left(\mathrm{Bq} \cdot \mathrm{kg}^{-1}\right)$ & ${ }^{232} \mathrm{Th}\left(\mathrm{Bq} \cdot \mathrm{kg}^{-1}\right)$ \\
\hline 1 & $119.6 \pm 8.4$ & $26.8 \pm 2.1$ & $34.9 \pm 3.9$ \\
\hline 2 & $53.7 \pm 6.0$ & $8.4 \pm 1.4$ & $53.6 \pm 5.9$ \\
\hline 3 & $334.7 \pm 18.4$ & $27.7 \pm 2.1$ & $32.8 \pm 3.7$ \\
\hline 4 & $246.8 \pm 14.2$ & $18.9 \pm 1.9$ & $38.7 \pm 4.3$ \\
\hline 5 & $104.8 \pm 7.8$ & $\mathrm{BDL}$ & $47.7 \pm 5.3$ \\
\hline 6 & $68.3 \pm 6.3$ & $10.9 \pm 1.7$ & $42.2 \pm 4.7$ \\
\hline 7 & $74.3 \pm 6.7$ & $25.6 \pm 2.0$ & $37.1 \pm 4.2$ \\
\hline 8 & $274.2 \pm 15.5$ & $19.0 \pm 1.9$ & $51.4 \pm 5.6$ \\
\hline 9 & $45.2 \pm 5.3$ & BDL & $45.1 \pm 5.0$ \\
\hline 10 & $185.5 \pm 11.3$ & $11.9 \pm 1.7$ & $51.3 \pm 5.6$ \\
\hline 11 & $437.5 \pm 23.5$ & $10.8 \pm 1.7$ & $39.4 \pm 4.4$ \\
\hline 12 & $484.2 \pm 25.9$ & $21.1 \pm 1.9$ & $35.8 \pm 4.0$ \\
\hline 13 & $133.1 \pm 9.0$ & $12.3 \pm 1.8$ & $22.8 \pm 2.7$ \\
\hline 14 & $163.3 \pm 10.3$ & $8.1 \pm 1.6$ & $41.0 \pm 4.6$ \\
\hline 15 & $334.3 \pm 18.4$ & $17.6 \pm 1.9$ & $54.4 \pm 5.9$ \\
\hline 16 & $253.4 \pm 14.5$ & $5.3 \pm 1.6$ & $56.0 \pm 6.1$ \\
\hline 17 & $441.3 \pm 23.7$ & $9.8 \pm 1.7$ & $39.4 \pm 4.5$ \\
\hline 18 & $128.5 \pm 8.8$ & $11.8 \pm 1.7$ & $40.7 \pm 4.5$ \\
\hline 19 & $292.7 \pm 16.4$ & $15.2 \pm 1.8$ & $58.0 \pm 6.3$ \\
\hline 20 & $57.9 \pm 6.2$ & $11.8 \pm 1.7$ & $53.6 \pm 5.9$ \\
\hline 21 & $133.1 \pm 8.9$ & $12.0 \pm 1.8$ & $22.8 \pm 2.7$ \\
\hline 22 & $165.0 \pm 10.4$ & $5.6 \pm 1.6$ & $44.8 \pm 4.9$ \\
\hline 23 & $271.5 \pm 15.3$ & BDL & $35.3 \pm 4.0$ \\
\hline 24 & $334.3 \pm 18.4$ & $17.6 \pm 1.9$ & $54.4 \pm 5.9$ \\
\hline 25 & $355.2 \pm 19.4$ & $10.1 \pm 1.7$ & $53.8 \pm 5.9$ \\
\hline 26 & $268.6 \pm 15.2$ & BDL & $62.4 \pm 6.8$ \\
\hline 27 & $335.0 \pm 18.4$ & $27.6 \pm 2.1$ & $32.8 \pm 3.7$ \\
\hline 28 & $68.9 \pm 6.5$ & $8.7 \pm 1.7$ & $25.3 \pm 3.0$ \\
\hline 29 & $440.5 \pm 23.7$ & $10.1 \pm 1.7$ & $39.3 \pm 4.4$ \\
\hline 30 & $456.2 \pm 24.4$ & $14.9 \pm 1.8$ & $35.1 \pm 4.0$ \\
\hline 31 & $118.2 \pm 8.3$ & $16.1 \pm 1.8$ & $33.9 \pm 3.8$ \\
\hline 32 & $482.7 \pm 25.8$ & $21.1 \pm 1.9$ & $35.7 \pm 4.0$ \\
\hline 33 & $254.2 \pm 14.5$ & $19.2 \pm 1.9$ & $39.0 \pm 4.4$ \\
\hline 34 & $292.9 \pm 16.4$ & $14.7 \pm 1.8$ & $57.4 \pm 6.3$ \\
\hline 35 & $138.8 \pm 9.2$ & $20.8 \pm 1.9$ & $39.5 \pm 4.4$ \\
\hline 36 & $336.5 \pm 18.5$ & $25.9 \pm 2.0$ & $28.6 \pm 3.3$ \\
\hline 37 & $164.1 \pm 10.3$ & $8.7 \pm 1.7$ & $41.0 \pm 4.6$ \\
\hline 38 & $279.7 \pm 15.8$ & $\mathrm{BDL}$ & $38.9 \pm 4.3$ \\
\hline Mean \pm SD & $240.2 \pm 133.5$ & $13.3 \pm 8.0$ & $40.0 \pm 10.2$ \\
\hline
\end{tabular}

SD denotes standard deviation, BDL denotes below detection limit. 
TABLE II

Activity concentrations of bitumen samples. Concentrations dans les échantillons de bitume.

\begin{tabular}{llll}
\hline $\mathrm{S} / N$ & ${ }^{40} \mathrm{~K}\left(\mathrm{~Bq} \cdot \mathrm{kg}^{-1}\right)$ & ${ }^{226} \mathrm{Ra}\left(\mathrm{Bq} \cdot \mathrm{kg}^{-1}\right)$ & ${ }^{232} \mathrm{Th}\left(\mathrm{Bq}^{-1} \mathrm{~kg}^{-1}\right)$ \\
\hline 1 & $84.1 \pm 7.0$ & $25.5 \pm 2.0$ & $41.7 \pm 4.6$ \\
2 & $32.6 \pm 1.7$ & $6.7 \pm 1.6$ & $23.2 \pm 2.8$ \\
\hline Mean \pm SD & $\mathbf{5 8 . 4} \pm \mathbf{3 6 . 4}$ & $\mathbf{1 6 . 1} \pm \mathbf{1 3 . 3}$ & $\mathbf{3 2 . 5} \pm \mathbf{1 3 . 1}$ \\
\hline
\end{tabular}

SD denotes standard deviation.

\subsection{Absorbed dose rate and annual effective dose}

The external outdoor absorbed gamma dose rate, $D\left(n G y \cdot h^{-1}\right)$, due to terrestrial gamma rays at $1 \mathrm{~m}$ above the ground is calculated from the activity concentrations of ${ }^{40} \mathrm{~K},{ }^{226} \mathrm{Ra}$ and ${ }^{232} \mathrm{Th}$. The equation is given as (UNSCEAR, 2000)

$$
D=0.0417 A_{K}+0.462 A_{U}+0.604 A_{T h}
$$

where $A_{K}, A_{U}$ and $A_{T h}$ are the activity concentrations of ${ }^{40} \mathrm{~K},{ }^{226} \mathrm{Ra}$ and ${ }^{232} \mathrm{Th}$ in Bq. $\mathrm{kg}^{-1}$, respectively. About $98 \%$ of the external gamma dose rate from the ${ }^{238} \mathrm{U}$ series is delivered by the ${ }^{226} \mathrm{Ra}$ subseries. So disequilibrium, if any, between ${ }^{226} \mathrm{Ra}$ and ${ }^{238} \mathrm{U}$ will not affect the dose estimation from the measurement of ${ }^{226} \mathrm{Ra}$ (Shanbhag et al., 2005). The absorbed dose rates for the soil samples varied between 22.2 and $54.9 \mathrm{nGy} \cdot \mathrm{h}^{-1}$, with a mean value of $(41.5 \pm 8.9) \mathrm{nGy} \cdot \mathrm{h}^{-1}$. For the bitumen samples, the absorbed dose rate was calculated as $(29.5 \pm 15.6) \mathrm{nGy} \cdot \mathrm{h}^{-1}$.

The annual effective dose, $E$, was calculated using a conversion factor and occupancy factor of $0.7 \mathrm{~Sv}_{\mathrm{G}} \mathrm{Gy}^{-1}$ and 0.2 , respectively. The conversion factor converts the absorbed dose in air into the effective dose in humans. The equation is given as (UNSCEAR, 2000; Asghar et al., 2008);

$$
E=D \times T \times 0.7 \times 0.2
$$

where $T$, the numbers of hours per year, is 8760 h. $\mathrm{y}^{-1}$. The results obtained ranged from 27.2 to $67.4 \mu \mathrm{Sv}_{\mathrm{y}} \mathrm{y}^{-1}$ with a mean value of $(50.7 \pm 10.9) \mu \mathrm{Sv}^{-\mathrm{y}^{-1}}$ for the soil samples. The mean effective dose of the bitumen samples was $(36.1 \pm$ 19.1) $\mu \mathrm{Sv} \mathrm{y}^{-1}$. The mean values of the absorbed dose rate and the effective dose of the soil samples are higher than those of the bitumen samples. However, they are lower than the world average values of $59 \mathrm{nGy} \cdot \mathrm{h}^{-1}$ and $0.07 \mathrm{mSv} \cdot \mathrm{y}^{-1}$ reported by UNSCEAR (2000). 


\subsection{Radium equivalent activity and external hazard index}

Natural radionuclides are not homogeneously distributed in soil. To represent the activity concentrations of ${ }^{40} \mathrm{~K},{ }^{226} \mathrm{Ra}$ and ${ }^{232} \mathrm{Th}$, a common index which takes into account the radiation hazards associated with all three radionuclides has been introduced and is called radium equivalent activity, $R a_{e q}$. The relation is given as (Beretka and Mathew, 1985; Ademola, 2008a)

$$
R a_{e q}=0.077 A_{K}+A_{R a}+1.43 A_{T h}
$$

where $A_{K}, A_{R a}$ and $A_{T h}$ are the activity concentrations of ${ }^{40} \mathrm{~K},{ }^{226} \mathrm{Ra}$ and ${ }^{232} \mathrm{Th}$ in $\mathrm{Bq} \cdot \mathrm{kg}^{-1}$, respectively. When defining equation (4), it is assumed that $13 \mathrm{~Bq} \cdot \mathrm{kg}^{-1}$ of ${ }^{40} \mathrm{~K}, 1 \mathrm{~Bq} \cdot \mathrm{kg}^{-1}$ of ${ }^{226} \mathrm{Ra}$ and $0.7 \mathrm{~Bq} \cdot \mathrm{kg}^{-1}$ of ${ }^{232} \mathrm{Th}$ deliver the same gamma dose rate. The maximum recommended limit of $R a_{e q}$ is $370 \mathrm{~Bq} \cdot \mathrm{kg}^{-1}$, which is equivalent to $1.5 \mathrm{mGy}^{-1} \mathrm{y}^{-1}$ (Krisiuk et al., 1971; Krieger, 1981). The radium equivalent activities of the soil and bitumen samples are presented in Tables III and IV. They vary from 50.2 to $121.1 \mathrm{~Bq} \cdot \mathrm{kg}^{-1}$, with a mean value of $(91.9 \pm 18.8) \mathrm{Bq} \cdot \mathrm{kg}^{-1}$ for the soil samples. The mean $R a_{e q}$ obtained for the bitumen samples is $(67.0 \pm 34.8) \mathrm{Bq}_{\mathrm{kg}}{ }^{-1}$. The radium equivalent activity obtained for both the soil and bitumen samples is lower than the recommended limit of $370 \mathrm{~Bq} \cdot \mathrm{kg}^{-1}$, which makes them suitable for construction purposes.

The external hazard index due to the emitted gamma rays of the samples is calculated according to the following criterion (OECD, 1979; Beretka and Mathew, 1985; Ademola, 2008b)

$$
H_{e x}=A_{K} / 4810+A_{R a} / 370+A_{T h} / 259 \leq 1
$$

where $A_{K}, A_{R a}$ and $A_{T h}$ are the activity concentrations of ${ }^{40} \mathrm{~K},{ }^{226} \mathrm{Ra}$ and ${ }^{232} \mathrm{Th}$, respectively. The value of this index must be less than unity for the radiation hazard to be acceptable. From the result obtained, the mean values for the soil and bitumen samples are less than unity. This implies that the radiation exposure due to the radioactivity in these samples when used as construction materials is less than $1.5 \mathrm{mSv}^{-1}{ }^{-1}$ (Beretka and Mathew, 1985).

\section{Conclusion}

The activity concentrations of natural radionuclides in bitumen and soil samples around a bituminous deposit in Ondo State, Nigeria, were analysed using gammaray spectroscopy. The mean activity concentrations of the natural radionuclides of both the soil and bitumen samples are lower than the world average. Consequently, the absorbed dose rate and effective dose are lower than the world average. The values of radium equivalent activity and the external hazard index calculated were 
TABLE III

Absorbed dose rate, effective dose, radium equivalent activity and external hazard index of soil samples. Débit de dose absorbée, dose effective, activité équivalente en radium et indice de détriment externe dans les échantillons de sol.

\begin{tabular}{|c|c|c|c|c|}
\hline$S / N$ & $D\left(\mathrm{nGy}^{\left.-\mathrm{h}^{-1}\right)}\right.$ & $E\left(\mu \mathrm{Sv} \cdot \mathrm{y}^{-1}\right)$ & $R a_{e q}\left(\mathrm{~Bq} \cdot \mathrm{kg}^{-1}\right)$ & $H_{e x}$ \\
\hline 1 & 38.4 & 42.2 & 85.9 & 0.23 \\
\hline 2 & 38.5 & 47.2 & 89.2 & 0.24 \\
\hline 3 & 44.5 & 54.6 & 100.4 & 0.27 \\
\hline 4 & 42.4 & 52.0 & 93.2 & 0.25 \\
\hline 5 & 33.2 & 40.7 & 76.3 & 0.21 \\
\hline 6 & 33.4 & 40.9 & 76.5 & 0.21 \\
\hline 7 & 37.3 & 45.8 & 84.4 & 0.23 \\
\hline 8 & 51.3 & 62.9 & 113.6 & 0.31 \\
\hline 9 & 29.1 & 35.7 & 68.0 & 0.18 \\
\hline 10 & 44.2 & 54.2 & 99.5 & 0.27 \\
\hline 11 & 47.0 & 57.7 & 100.8 & 0.27 \\
\hline 12 & 51.6 & 63.2 & 109.6 & 0.30 \\
\hline 13 & 25.0 & 30.7 & 54.9 & 0.15 \\
\hline 14 & 35.3 & 43.3 & 79.3 & 0.21 \\
\hline 15 & 54.9 & 67.4 & 121.1 & 0.33 \\
\hline 16 & 46.8 & 57.4 & 104.9 & 0.28 \\
\hline 17 & 46.7 & 57.3 & 100.1 & 0.27 \\
\hline 18 & 35.4 & 43.4 & 79.9 & 0.22 \\
\hline 19 & 54.3 & 66.5 & 120.7 & 0.33 \\
\hline 20 & 40.2 & 49.4 & 92.9 & 0.25 \\
\hline 21 & 24.9 & 30.5 & 54.9 & 0.15 \\
\hline 22 & 36.5 & 44.8 & 82.4 & 0.22 \\
\hline 23 & 32.6 & 40.0 & 71.4 & 0.19 \\
\hline 24 & 54.9 & 67.4 & 121.1 & 0.33 \\
\hline 25 & 52.0 & 63.7 & 114.4 & 0.31 \\
\hline 26 & 48.9 & 60.0 & 109.9 & 0.30 \\
\hline 27 & 46.5 & 57.1 & 100.3 & 0.27 \\
\hline 28 & 22.2 & 27.2 & 50.2 & 0.14 \\
\hline 29 & 46.8 & 57.4 & 100.2 & 0.27 \\
\hline 30 & 47.1 & 57.8 & 100.2 & 0.27 \\
\hline 31 & 32.8 & 40.3 & 73.7 & 0.20 \\
\hline 32 & 51.4 & 63.1 & 109.3 & 0.30 \\
\hline 33 & 43.0 & 52.8 & 94.5 & 0.26 \\
\hline 34 & 53.7 & 65.8 & 119.3 & 0.32 \\
\hline 35 & 39.3 & 48.1 & 88.0 & 0.24 \\
\hline 36 & 43.3 & 53.1 & 92.7 & 0.25 \\
\hline 37 & 35.6 & 43.7 & 80.0 & 0.22 \\
\hline 38 & 35.2 & 43.1 & 77.2 & 0.21 \\
\hline Mean \pm SD & $41.5 \pm 8.9$ & $50.7 \pm 10.9$ & $91.9 \pm 18.8$ & $0.25 \pm 0.05$ \\
\hline
\end{tabular}

SD denotes standard deviation. 


\section{TABLE IV}

Absorbed dose rate, effective dose, radium equivalent activity and external hazard index of bitumen samples.

Débit de dose absorbée, dose effective, activité équivalente en radium et indice de détriment externe dans les échantillons de bitume.

\begin{tabular}{lllll}
\hline$S / N$ & $D\left(\mathrm{nGy} \cdot \mathrm{h}^{-1}\right)$ & $E\left(\mu \mathrm{Sv} \cdot \mathrm{y}^{-1}\right)$ & $R a_{e q}\left(\mathrm{~Bq} \cdot \mathrm{kg}^{-1}\right)$ & $H_{e x}$ \\
\hline 1 & 40.5 & 49.6 & 91.6 & 0.25 \\
2 & 18.5 & 22.6 & 42.4 & 0.11 \\
Mean \pm SD & $\mathbf{2 9 . 5} \pm \mathbf{1 5 . 6}$ & $\mathbf{3 6 . 1} \pm \mathbf{1 9 . 1}$ & $\mathbf{6 7 . 0} \pm \mathbf{3 4 . 8}$ & $\mathbf{0 . 1 8} \pm \mathbf{0 . 1 0}$ \\
\hline
\end{tabular}

SD denotes standard deviation.

lower than the recommended limits. It can therefore be concluded that the samples examined do not pose any significant radiation hazard and can be used for construction purposes. It can also be concluded that the presence of bitumen in the study area has no adverse effect on the soil as far as radiation is concerned.

\section{REFERENCES}

Adegoke O.S., Ibe E.C. (1982) The tar-sand and heavy crude resources of Nigeria, Proc. 2nd Intern. Conf. on the Heavy Crude and Tar-sands (Caracas, Venezuela).

Adegoke O.S., Omatsola M.E., Coker J.L. (1991) The geology of the Nigerian tar-sands. In: Heavy Crude and Tar-sands Hydrocarbons for the 21st Century, Proc. 5th UNITAR Intern. Conf. on Heavy Crude and Tar-Sands (Salt Lake City, Utah, USA).

Ademola J.A. (2008a) Exposure to high background radiation level in the tin mining area of Jos Plateau, Nigeria, J. Radiol. Prot. 28, 93-99.

Ademola J.A. (2008b) Assessment of natural radionuclide content of cements used in Nigeria, J. Radiol. Prot. 28, 581-588.

Asghar M., Tufail M., Sabiha-Javied Abid A., Waqas M. (2008) Radiological implications of granite of northern Pakistan, J. Radiol. Prot. 28, 387-399.

Beretka J., Mathew P.J. (1985) Natural radioactivity of Australian building materials, industrial waste and by-products, Health Phys. 48, 87-95.

Boyle R.U. (1982) Geochemical prospecting for thorium and uranium deposit, Developm. Economics Geology 16, 71-78.

CBEIR NRC (1988) Committee on the Biological Effects of Ionizing Radiations, National Research Council. Health Risks of Radon and Other Internally Deposited Alpha-Emitters: BEIR IV. National Academy Press, Washington, D.C.

Enu I.I. (1994) Textural characteristics of the Nigerian tar sands, Sedimentary Geology 33, 57-61.

Farai I.P., Ademola J.A. (2005) Radium equivalent activity concentrations in concrete building blocks in eight cities in Southwestern Nigeria, J. Environ. Radioact. 79, 119-125.

IAEA (1989) International Atomic Energy Agency. Measurements of radionuclides in food and the environment - A Guidebook. STI/DOC/10/295 IAEA Vienna.

Kathren R. (1991) Radioactivity in the environment. Taylor and Francis Pub, USA.

Kribek B., Zak K., Spangenberg J.E., Jehlicka J., Prokes S., Kominek J. (1999) Bitumens in the late Variscan hydrothermal vein-type uranium deposit of Pribram, Czech Republic; sources, radiation-induced alteration, and relation to mineralization, Economic Geology 94, 1093-1114. 
Krieger R. (1981) Radioactivity of construction materials, Betonwerk Fertigteil-Tech 47, 468-473.

Krisiuk E.M., Tarasov S.I., Shamov V.P., Shalak N.I., Lisachenko E.P., Gomelsky L.G. (1971) A Study of Radioactivity in Building Materials. Research Institute for Radiation Hygiene, Leningrad.

OECD (1979) Organization of Economic Cooperation and Development. Exposure to radiation from natural radioactivity in building materials, Report by a Group of Experts of the OECD. Nuclear Energy Agency, Paris.

Omatsola M.E., Adegoke O.S. (1981) Tectonic evolution and cretaceous stratigraphy of the Dahomey Basin, Niger. J. Mining Geol. 18, 130-137.

Shanbhag A.A., Sartandel S.J., Ramachandran T.V., Puranik V.D. (2005) Natural radioactivity concentrations in beach sand of Ratnagiri coast, Maharastra, J. Assoc. Environ. Geochem. 8, 304-308.

UNSCEAR (2000) United Nations Scientific Committee on the Effects of Atomic Radiation. Sources and Effects of Ionizing Radiation, Vol. 1: Sources. 2000 Report to the General Assembly, with scientific annexes. Annex B: Exposures from natural radiation sources (New York, United Nations). 